\title{
A razão governamental de Alberto Torres
}

\author{
Alexandre de Paiva Rio Camargo'
}

\section{Resumo}

O artigo investiga a obra de Alberto Torres sob o ponto de vista da introdução de uma razão governamental no pensamento político brasileiro, pautada pela lógica da prevenção e da estruturação do campo de ações possíveis. Parte das reflexões de Michel Foucault sobre a governamentalidade para examinar a visão torreana de modernização e procura mostrar que a arquitetura do Estado desenhada em A organização nacional e O problema nacional brasileiro é inseparável das medidas destinadas a produzir o "homem novo" como sujeito ético capaz de enfrentar os riscos da vida social, o que constitui um marco de ruptura na tradição do pensamento político e social. A razão governamental é analisada quanto aos seguintes aspectos: a influência da sociabilidade da escravidão na concepção de população, baseada na lógica afetiva e nas interações comunitárias; a reforma do regime jurídico e a formação de um regime de opinião, na direção de um governo das percepções; o lugar da política racial e do povoamento territorial na expansão da capacidade administrativa do Estado e na regulação da agência humana.

Palavras-chave: Governamentalidade. Política de População. Coordenação Nacional. Pensamento Social. Primeira República.

\section{Introdução}

O presente texto propóe uma leitura alternativa da obra de Alberto Torres (1865-1917), por ocasiáo do centenário de seu falecimento. Em primeiro lugar, porque ela permanece insuficientemente compreendida. Predominam interpretaçóes de segunda mão a seu respeito, escritas por intelectuais que reivindicaram sua paternidade para se apropriar de seu

I Professor adjunto do Programa de Pós-Graduação em Sociologia Política da Universidade Candido Mendes (PPCSP-UCAM). Doutor em Sociologia pelo Instituto de Estudos Sociais e Políticos (IESP) da Universidade do Estado do Rio de Janeiro (UERJ); Mestre e Bacharel em História pela Universidade Federal Fluminense (UFF). E-mail: alexandre.camargo.2009@gmail.com

$(\infty)$ EY
Direito autoral e licença de uso: Este artigo está licenciado sob uma Licença Creative Commons. Com essa licença você pode compartilhar, adaptar, para qualquer fim, desde que atribua a autoria da obra, forneça um link para a licença, e indicar se foram feitas alterações. 
legado segundo seus próprios objetivos e suas visóes da política e da sociedade. Este é o caso notório, certamente não único, de Oliveira Vianna, seu principal difusor nos anos 1920 e 1930 . Em segundo lugar, porque parte expressiva da abundante literatura a seu respeito tende a privilegiar sua obra pelos elementos ideológicos que encerra, vendo nela as bases do pensamento nacionalista (MARSON, 1979) e autoritário (LAMOUNIER, 1985) entre nós. São numerosos os trabalhos que relacionam os escritos de Torres à recepçáo do vitalismo e do solidarismo no contexto de uma sociedade clânica, carente de continuidade política e unidade de ação pública (SANTOS, 1978; IGLÉSIAS, 1978; LEMOS, 1995)

Neste cenário, sente-se a ausência de um estudo sobre as possíveis homologias entre o universo semântico de seu pensamento e a montagem do Estado que se organiza a partir da revolução de 1930, cujas bases começam a ser desenhadas nos anos que seguem a publicação de $A$ organização nacional e $O$ problema nacional brasileiro ${ }^{2}$. Ou seja, um estudo sobre a circularidade entre as categorias mobilizadas nestas obras e o aparecimento, em outros atores e marcos institucionais, de uma ideia de sujeito inseparável da concepçáo de Estado. Ao se debruçar sobre o tema da construção do Estado, as obras acima relacionadas tenderam a abordá-lo sob o prisma da polarização entre liberalismo e autoritarismo. Ressentem-se de um exame mais detido sobre as relaçóes entre a arquitetura do Estado e a produção do cidadão enquanto sujeito ético, manifesta na inédita - e, logo, generalizada - preocupação com os saberes e práticas que deveria possuir o homem nacional, de modo a viabilizar o tão desejado "homem novo", este elo entre o tradicional e o moderno, entre a cultura e a civilização.

Considerado um dos primeiros porta-vozes da questão social entre nós, e, possivelmente, o primeiro a convertê-la em "questão nacional", Torres viu na construçáo do Estado a condição tanto da esfera pública quanto da personalidade moral do "homem nacional". Visão que não se reduziu aos liames do pensamento autoritário, instalando-se como credo entre as elites

2 Ambos os liuros foram originalmente publicados como série de artigos na imprensa carioca. No caso de A organização nacional, os artigos foram editados entre novembro de 1910 e fevereiro de 191 I na Gazeta de Notícias. Já O problema nacional brasileiro é uma combinação de um discurso proferido no Instituto Histórico Geográfico Brasileiro, em 19II, e alguns artigos publicados no Jornal do Commercio, em 1912. 
intelectuais condutoras do país. Por "homem nacional", entenda-se uma posição de sujeito consagrada, sobretudo, pela retórica política promovida no contexto das publicaçóes referidas, das campanhas de saneamento e combate ao analfabetismo; da organização do ensino técnico, comercial e profissional garantidos por convênios entre a União e os estados; da obrigatoriedade legal do ensino primário; da fixação das bases de um regime de seguro e assistência social (HOCHMAN, 1998; NAGLE, 2006, p. 283).

Em conjunto, tais iniciativas parecem ter concorrido efetivamente para a formação de uma opinião pública nacional, mobilizada pelo desenvolvimento da consciência de interdependência social, como sugere a formação das inúmeras ligas e associaçôes voluntárias, dedicadas à promoção do trabalho, da assistência, da educação e da saúde . Em tal discurso, "o homem nacional" aparece sem ter por referência a cidadania ou a agência econômica, e sim a figura passiva do abandonado e degenerado, a ser recuperado e ressocializado por técnicas de si promovidas pelo poder público, como a estética, a higiene pessoal, e a educação alimentar e profissional. Em seus trabalhos sobre a governamentalidade, Michel Foucault mostrou como as técnicas de si importam para as formas de subjetivaçáo facilitadas por diferentes regimes de ação pública; afinal, elas permitem aos indivíduos "[...] efetuarem, sozinhos ou com ajuda de terceiros, certo número de operaçóes sobre seu corpo e sua alma, seus pensamentos, suas condutas, seu modo de ser, de maneira a se transformar a fim de alcançar um estado de felicidade, pureza, sabedoria, perfeição ou imortalidade"4 (FOUCAULT, 1994, p. 785).

Em Segurança, território, população (2008) e O nascimento da biopolítica (2009), Foucault alçou o liberalismo ao centro da análise, por entender que o governo se torna mais capilar e eficiente ao produzir liberdades e tematizá-las como fundamento da autoridade. Essa seria a ruptura profunda do liberalismo com as artes de governo que lhe antecederam, uma vez que nele os modos de pensar e fazer o Estado se articulam com as técnicas de si,

3 Entre as principais associações atuantes nos anos 1910 e 1920, contam-se a Liga de Defesa Nacional, a Liga Pró-Saneamento do Brasil, a Liga Brasileira Contra o Analfabetismo, a Liga Nacionalista e a Liga Brasileira contra a Tuberculose. Juntas, as ligas mobilizaram estratos superiores e médios em torno da formação de uma agenda de assistência social.

4 Diferentemente das técnicas de dominação, que determinam a conduta dos individuos e objetivam os sujeitos, submetendo-os a certos processos e fins, o que é o caso das técnicas disciplinares. 
destinadas à transformação da conduta mediante aprimoramento pessoal, como as regras de etiqueta, a direção espiritual e a prescrição de modelos de vida. Trata-se, portanto, de uma progressiva aproximação entre a estatização das esferas sociais e as técnicas de si. $\mathrm{O}$ universalismo que tais técnicas poderiam atingir esteve limitado, até então, pela centralidade da moral aristocrática e sua conhecida indiferença em relação a sistemas de crença e organização da vida camponesa e plebeia. Já no liberalismo, a sociedade representa ao mesmo tempo "o conjunto das condiçóes do governo mínimo liberal" e a "superfície de transferência da atividade governamental" (FOUCAULT, 2009 apud SENNELART, 2009, p. 446).

O desafio que nos colocamos neste artigo é examinar a obra Torres à luz de uma nova mentalidade de governo, que problematiza as técnicas de si, a mediação estatal das relaçóes sociais, e seus efeitos sobre a conduta dos governados. Entendemos que a contribuição foucaultiana (FOUCAULT, 2008, 2009) permite problematizar satisfatoriamente a questão da emergência de uma razão governamental no Brasil, ao apreendê-la como a formação discursiva de uma estratégia geral de poder orientada pela lógica da prevenção, ou seja, pela estruturação do campo de açóes possíveis dos indivíduos. Estratégia que apenas se torna transparente à análise quando se valorizam as transversalidades entre o estatal e o não estatal, entre as instituições da ordem pública e as formas de induzir a conduta na vida privada, que fazem do governo uma empresa coletiva e reflexiva em relação aos seus domínios de atuação.

Para tanto, utilizaremos o conceito de governo em sentido ampliado, segundo a perspectiva foucaultiana que foi esboçada. Do mesmo modo, referimo-nos ao governo liberal enquanto campo de possibilidades da agência social, a partir do qual técnicas de si e instituiçôes garantidas ou certificadas pelo Estado visam a incitar e induzir determinadas açóes em detrimento de outras. Por um lado, isso quer dizer que nos afastamos de abordagens clássicas da teoria política sobre o liberalismo, como as que se interessam pela soberania, pela legitimidade e pela estrutura de funcionamento do Estado. Por outro lado, tal opção permite examinar a matriz de governo liberal como pano de fundo do pensamento torreano, inclusive quando procura dela se afastar, ou dialogar com tradiçóes conservadoras que reconhecem a autonomia das dinâmicas sociais em relação à ordem política. 
A seguir tal entendimento, Torres não se notabilizaria tanto como pai fundador de uma escola de pensamento político, seja por seu "autoritarismo instrumental", que corrigiria o liberalismo deslocado em uma sociedade clânica para fundar a solidariedade social (SANTOS, 1978, p. 93), seja por seu autoritarismo tout court, ao "conceituar e legitimar a autoridade do Estado como princípio tutelar da sociedade" (LAMOUNIER, 1985, p. 356). A interpretação de Bolívar Lamounier consagrou Torres como um dos expoentes do pensamento autoritário, ao preconizar o predomínio do Estado sobre o mercado, a visão orgânico-corporativa de sociedade, o objetivismo tecnocrático e o voluntarismo elitista como fator de mudança. O problema desta leitura é tomar a obra de Torres pelas apropriaçóes que dela fizeram os seguidores que reivindicaram o seu legado, como é o caso do movimento integralista dos anos 1930, e do nacionalismo racista e autoritário de Oliveira Vianna ${ }^{5}$. Em consequência, ficaram apagados os preceitos do liberalismo clássico que, explícita ou implicitamente, estão na base do seu pensamento. Preceitos que levaram autores como Adalberto Marson a chamarem-no de "liberal-nacional, conservador, mas não necessariamente autoritário” (MARSON, 1979, p. 42-43). Entre os traços liberais, encontramos a crença na bondade natural do homem, a defesa do sufrágio universal (mesmo que corrigido por outras formas de representaçáo) e a recusa a qualquer argumento de caráter racial como fundamento da diferença entre os homens.

Neste artigo, propomos uma leitura diversa daquelas seguidas pelos autores citados. Abordaremos Torres como o sistematizador de uma mentalidade de governo que traz o problema da prevenção para o centro da reflexão política e da análise social, a partir dos anos 1910. Veremos como sua obra nos permite pensar os elementos estruturantes de uma razão governamental baseada na operacionalização das condutas que, ao mesmo tempo, articula e se afasta da tradição liberal.

É importante considerar que a crítica desenvolvida por Torres à ordem oligárquica é um espelho da situação fluminense. Em nenhum outro

5 Esta ascendência aparece, pela primeira vez, no manifesto em forma de coletânea de artigos, coordenada por Vicente Licínio Cardoso e publicada em 1924, sugestivamente intitulada $A$ margem da história da república, onde os autores rendem tributo ao mestre. Por fim, nos anos 1930. Alberto Torres alcançaria a mitificação como "tema de uma geração", na consagrada expressão de Cândido Mota Filho. Sua obra sobre a "organização nacional" batizaria a agenda política que sucede a revolução de 1930 e marcaria as publicações mais relevantes, caso da Constituição de 1934, em grande parte inspirada em seu projeto de revisão da Carta de 1891. 
lugar, a abolição e a República contribuíram tanto para a desorganização do trabalho e da lavoura, em uma região que já se mostrava decadente. Tanto que as posiçóes dissidentes de Torres começaram a aparecer justamente após seu mandato na presidência do estado do Rio de Janeiro (1897-1899), momento em que se evidenciou para ele a dependência da monocultura e os hábitos resilientes de uma elite senhorial resistente à modernização do sistema produtivo (FERNANDES, 2010, p. 99-100). Cabe, então, começar nosso exame pelo lugar que a sociabilidade da escravidão ocupa em seu projeto de modernização.

\section{Da escravidão à razão afetiva como guia da conduta}

A tese que atribui "prioridade à formação da nacionalidade sobre a sociedade" informa todo o pensamento torreano (TORRES, 1982, p. 50). Ao contrário da tradição do pensamento liberal, não há naturalidade nem anterioridade da sociedade relativamente ao Estado. A formação da sociedade virá dos mecanismos governamentais que potencializem os feitos do Estado para além das margens estreitas da representação política, em proveito da regulação de uma população ainda reduzida a "[...] aglomerados dispersos de famílias, classes, associaçóes, partidos, profissóes, raças, nacionalidades e religiôes" (TORRES, 1982, p. 43). Será pela ação governamental sobre estas coletividades que se poderão produzir os vínculos morais da solidariedade social.

Já a escravidão é vista como a única instituição organizada da colônia e do império, servindo de base à sua ideia de população:

[...] como população, situada entre a classe senhorial e os escravos, [...] havia a imensa massa dos 'agregados', famílias de indivíduos ociosos, analfabetos, mal nutridos, morando nos 'sítios', desprezados das fazendas, que só apareciam nos 'jongos' dos dias de festa, e de cujo serviço só havia notícia nas anedotas picantes da domesticidade dos fazendeiros. (TORRES, 1978, p. 100).

Essa massa de jornaleiros, rendeiros, caboclos e livres pobres que cresceu à revelia da autoridade privada do senhor e da subserviência do escravo, tornar-se-ia na república "[...] o conjunto dos aglomerados rurais e urbanos, que não são nem capitalistas nem proletários, e cujos interesses não se apresentam com o aspecto dos conflitos entre capital e trabalho" (TORRES, 1978, p. 47). 
É essa população, identificada com o embrião adormecido da nacionalidade, ameaçada pela sociedade clânica herdada do cativeiro e pela concorrência desleal com o estrangeiro por postos de trabalho, que cumpre formar e solidarizar, de modo a alçar a política comercial do Estado Oligárquico, baseada na troca, na especulação financeira e na extração de riqueza, a uma política econômica, centrada no trabalho, na produção e no consumo.

A centralidade assumida pela escravidão em Torres não se esgota nos obstáculos que antepóe à obra de "organização nacional". Parece-nos que a escravidão aparece como forma de sociabilidade que estrutura as relaçóes entre o indivíduo e a sociedade que se quer organizar.

Em primeiro lugar, o diagnóstico da inexistência da sociedade e da urgência de formá-la remete às condiçôes de socialização propícias ao desenvolvimento do homem novo. Tais condiçôes devem observar um pressuposto vitalista muito caro ao autor: a consciência é formada pela precedência do afeto como fonte de modelação social (TORRES, 1982, p. 30). Por conseguinte, para superar a mentalidade "leviana e volúvel" herdada da escravidão, a solidariedade deve ser fundada na excitaçáo do sentimento e da percepção, que dão forma ao juízo moral sobre a realidade e consistência afetiva ao vínculo:

[...] a autonomia de um povo nasce em sua consciência: a raiz da personalidade é a mesma, no homem e na sociedade. Ter consciência significa possuir os poderes de sensação e de percepção, o de formar juízos concretos, sobre as coisas; juízos abstratos, sobre as ideias; juízos morais, que são como a faculdade superior do afeto. O sentimento é a razão da natureza emocional. (TORRES, 1978, p. 47, grifo do autor).

Assim compreendida, a personalidade moral do indivíduo é já a sua consciência nacional. Mais do que expor a influência do vitalismo, este raciocínio esgota toda a individualidade na sua socialização e toda a socialização no agenciamento emocional, enquanto faz da sociedade a base orgânica da nacionalidade. Não poderia ser maior o contraste com o governo liberal, em que a produção de sujeitos autônomos e responsáveis passa pela transferência da atividade governamental para a superfície da sociedade (FOUCAULT, 2009, p. 446). Governar é aqui empoderar os sujeitos de modo a individualizá-los; torná-los cientes dos princípios gerais que presidem o governo econômico; estimular a racionalidade 
econômica dos indivíduos, atribuindo-lhes capacidades que tornam aquelas liberdades governáveis, ao favorecer o desenvolvimento de uma psicologia cognitiva compatível com o cálculo dos riscos. Para Foucault (2009), reside aí a produtividade política do liberalismo: fornece a crítica ao "excesso de governo" no mesmo movimento em que constitui fonte da conduta de si.

$\mathrm{Na}$ obra de Torres, encontramos diferentes passagens em que a afetividade, e não a racionalidade, aparece como motor da mentalidade e do juízo moral. $\mathrm{O}$ indivíduo não é mais do que o reflexo de uma socialização completa, dirigida e coordenada pelo governo: "[...] a sociedade faz o indivíduo: não pode produzir indivíduos úteis uma sociedade que se não acamou em seu leito natural - que não coordenou a sua direção" (TORRES, 1978, p. 51-52). Se não há sociedade, muito menos há vontades que sejam reconhecidas como fundamento da ação governamental. No lugar do empoderamento de vontades soberanas, encontramos um sujeito moral descolado de dispositivos e práticas de individualização, concebido não pela sua liberdade contratual, e sim pelo intercâmbio afetivo, manifesto no convívio comunitário das colônias agrícolas; pela psicologia emocional, vinculando suas decisóes e seus interesses à perspectiva do futuro da prole; pela orientação da percepção, com a educação voltada para o trabalho e para as formas de cultivar a terra, negociar a produção e se preparar para as intempéries; e pelo disciplinamento dos corpos, com os cuidados com o consumo alimentar, a educaçáo física e os hábitos higiênicos.

Se estamos longe do contratualismo liberal e de qualquer concepção atomística de sociedade, estamos perto da razão governamental, uma vez que se trata de promover a personalidade moral pela regulaçáo das condutas. Entre estas, contam-se, por exemplo, a organização do crédito ao produtor agrícola, estimulando sua contabilidade pessoal; a administração de suas decisóes pelo conhecimento das operaçóes creditícias do regime comercial (TORRES, 1978, p. 205-206); o oferecimento gratuito do ensino primário e agrícola vinculado à necessidade de comprovar titulação para o exercício da profissão (TORRES, 1978, p. 272-273).

O seguinte fragmento é particularmente claro a este respeito: 
[...] com o desenvolvimento da ambição, fundada no trabalho, apura-se o zelo pela sorte da família: o sentimento humano - disperso até então por toda espécie de crenças - torna-se objetivo, concentrando-se nos laços das afeições reais: o amor vai absorvendo a fé, a divindade vivifica-se nas diversas formas do ideal, que, para as almas mais simples, se resume no problema da sorte dos filhos. (TORRES, 1978, p. III).

Notemos que a preocupação com a estabilidade familiar e com o "futuro da prole" delimitam a natureza da vontade que o governo imaginado por Torres deve procurar estimular: circunscreve o crescimento, a vitalidade e a produção das famílias como objeto de governo, deixando de lado as vontades contratuais e deliberativas, sem as quais é difícil falar no sujeito responsável alvejado pelo liberalismo. A família é, para nosso autor, a unidade produtiva que deve servir de objeto a um governo. Visualizada como entidade orgânica e totalizante, a família é alvejada como célula de subjetivação; o indivíduo somente é tematizado pelo valor que ganha por meio da socialização familiar.

Não chega a ser surpreendente, portanto, que "a política nacional", leia-se resultante do governo, "[...] se possa definir como atividade espontânea da sociedade, na defesa de seu caráter e de sua economia” (TORRES, 1982, p. 130). Tampouco que a política:

[...] resulte de um instinto da própria nacionalidade, isto é, de certo número de hábitos gravados hereditariamente nos organismos, transmitidos pela tradição, que conservam o vínculo do interesse coletivo, a consciência dos perigos comuns, o senso do auxílio mútuo, da solidariedade e da cooperação, fixados de maneira secular, entre indivíduos relativamente semelhantes habitando a mesma terra. (TORRES, 1982, p. 130).

Em outras palavras, uma vez que a política esteja unificada pela arte do governo, a nacionalidade torna-se instintiva, inscreve-se nos corpos que perfazem a totalidade do organismo vivo; o vínculo moral se estabiliza pelo comportamento autômato, antítese da reflexividade; a consciência flui em um meio não consciente; a conduta pública, enfim, transmite-se pela tradição e pela hereditariedade.

Parece-nos que este arcabouço vitalista, longe de ser apenas uma filiação ideológica do autor, constitui um modo de visualização da população. Uma visualização marcada pela dimensão pré-política, quando considerada do ponto de vista da sociedade, e pela dimensão não racional, em relação 
aos indivíduos que a compóem. Desse modo, a contribuição de Torres se destaca pelo esvaziamento das associaçôes com objetivos puramente políticos, julgadas incapazes de capacitar e habilitar seus participantes. $\mathrm{O}$ sujeito de trabalho deve ser produzido pela educação moral, sanitária, alimentar, profissional; não pela participação no jogo político ou pela construçáo da autonomia e da responsabilidade; em uma palavra, pela individualização.

Vemos que a obra de Torres estabelece as bases normativas de rompimento com a sociedade clânica e com a ordem oligárquica do liberalismo sem mercado e da política sem partidos representativos da opiniáo. Paradoxalmente, porém, este quadro é atingido pelo prolongamento da sociabilidade da escravidão, projetando a população a partir da sua exclusão da referência à política e da privação da capacidade deliberativa. Como resultado, o processo de individualização não seria forjado na experiência política e no interesse econômico, mas em um conjunto de relaçóes sociais mediadas e garantidas pelo Estado.

\section{Entre a revolução cultural e contrarrevolução política}

Escapa aos comentaristas do pensamento de Torres que, embora ele se volte para os temas da divisão do trabalho e da institucionalização dos conflitos, seu discurso não parte da sociedade atomística como ordem de valor - com sua ênfase na impessoalidade, na utilidade e na livre associação -, mas à comunidade, com sua referência à dependência como necessidade espontânea do organismo vivo. Em vez de mitigar as solidariedades locais fundadas na família, no parentesco e na vizinhança, a regulaçáo do Estado deveria se basear nas relaçóes de reciprocidade, de modo a diluir os efeitos do tradicionalismo, sem introduzir o individualismo no meio social.

Se a problematização da população "não se apresenta com o aspecto dos conflitos entre capital e trabalho" (TORRES, 1978, p. 47), a questão social pode ser travestida de questão nacional, como o farão seus portavozes dos anos 1910 e 1920. Não somente as associações de classe e ajuda mútua, como também as alianças territoriais, os compadrios políticos, e até mesmo as devoçóes religiosas, quando extremadas, se tornam fatores de pulverização da nacionalidade e obstáculos à mentalidade do mérito e do empreendimento, que, segundo o autor, somente poderiam encontrar 
suporte na mediação do Estado, único agente capaz de acolher as diversidades e coordenar as energias.

Quando se põe a defender a razão governamental, a política em si é justamente a ausência mais sentida. Não há menção aos mecanismos de participação, às condiçóes da atividade legislativa ou às regras eleitorais, como a restrição do voto aos alfabetizados, em um país com número de analfabetos estimado em 76\% por José Murilo de Carvalho (2010, p. 65), e a conveniência do voto secreto, já então bandeira dos congressistas liberais, liderados por Ruy Barbosa e Assis Brasil. Se não está claramente de acordo, Torres não se pronuncia contra a natureza extremamente restrita da participação popular e a manipulação fraudulenta do voto na prática política do liberalismo oligárquico.

A política não serve de prisma para a crítica da arquitetura do Estado Oligárquico, que deve ser buscada na razão governamental, orientada para a promoção de uma revolução cultural, isto é, uma revolução silenciosa e gradual da mentalidade de governo. Por tal razão, não representa uma ameaça desde o interior do establishment oligárquico, como sugere a opção por materializar suas diretrizes programáticas em um projeto de reforma da constituição. Ao contrário, tais diretrizes tinham por fim prevenir a possibilidade de que as agitaçóes sociais e políticas rompessem de forma traumática com o ordenamento jurídico.

As propostas sistematizam de forma normativa sua análise sociológica sobre os problemas nacionais. Em um primeiro eixo, encontra-se a redistribuição de prerrogativas e poderes entre os entes federativos, de modo a garantir a soberania nacional pelo fortalecimento da União e pela realização de acordos de cooperação com estados e municípios. A criação de rotinas burocráticas contornaria o caráter disruptivo da política, mediante a representação corporativa por profissóes e da implantação do poder coordenador e de um conselho nacional, órgão supremo que visaria a moralizar e fiscalizar a autoridade dos três níveis federativos, atuar como árbitro de seus conflitos, orientar a política tributária, organizar o trabalho e a assistência mútua e dirigir o aparelho produtivo (TORRES, 1978, p. 259-265).

Em um segundo eixo, encontramos a formulação de uma política de população capaz de dinamizar a relação entre produção e consumo, orientar 
os investimentos pela densidade demográfica e pelas características da ocupação do território, revitalizar o homem nacional pelo cuidado com o corpo, a alimentação e a higiene física e mental, universalizar a educação primária e profissional, condição de criação de um sujeito de trabalho.

Esses dois eixos não estão separados. Ao contrário, as agências de regulação e moralização antevistas por Torres teriam como alvo preferencial os hábitos arraigados e os comportamentos cristalizados, reprogramando-os segundo os imperativos de uma economia dirigida pelo Estado. Desse modo, favoreceriam a produção de mentes e corpos saudáveis e disciplinados, capazes de administrar o tempo e reagir às intempéries eventuais da carestia, da enfermidade, da crise de produção e da falta de trabalho, por meio da criação de mecanismos de proteção condicionada à observação de condutas desejadas: recurso ao crédito, seguro contra acidentes de trabalho, caixa de assistência, suporte em matéria de finanças e produção agrícola etc.

Como exemplo, vale mencionar que o projeto de revisão constitucional condicionava a atribuição de direitos políticos e civis ao exercício regular de uma profissão, que, por sua vez, apenas poderia ser obtida mediante conclusão do ensino elementar:

[...] o ensino primário e o profissional agrícola, no campo, serão gratuitos, sendo condição do exercício dos direitos políticos e civis a posse de um título conferido pelas escolas primárias e o exercício de uma profissão, com a necessária habilitação técnica. Nenhum indivíduo será declarado maior, para os efeitos da capacidade civil e política, sem exame que prove sua idoneidade física e mental e sem que satisfaça os requisitos deste artigo. (TORRES, 1978, p. 272-273).

A dupla exigência que atrela o direito ao voto ao exercício profissional e este à obtenção de escolaridade mínima sugere uma saída para o seguinte impasse: como a razão governamental pode promover a formaçáo táo necessária do caráter do povo sem recair no risco do protagonismo político das massas? Dito de outra forma, como manter o controle e o baixo grau de participação das massas em uma ordem pública autônoma garantida pelo Estado? Formando um regime de opiniâo pública e reformando o regime jurídico vigente, o que permite promover a operacionalização das condutas e o governo da opinião, deixando intocados os temas políticos 
mais sensíveis às oligarquias estaduais, tais como a organização dos partidos, o voto aberto, as regras eleitorais e a participação popular.

Para serem realmente representativas, é necessário que as eleiçóes - enquanto expressão da vontade política - se subordinem ao regime da opinião pública, o qual é o único que pode "exprimir a natureza mental do povo", seu grau de autoconsciência, sem o que apenas resta a violência do desejo passional da maioria e o cerceamento das liberdades praticado por partidos e outros agrupamentos políticos (TORRES, 1978, p. 90).

Assim, é o regime das opinióes que deve ser visado pela ação governamental. Eis a instância onde se encontra a clivagem entre os que podem e os que náo podem participar ativa e legitimamente da construçáo da esfera pública. Já que os partidos atuam como forças contrárias ao incitamento da corrente de ideias, serão "os centros intelectuais ativos, operando com energia e liberdade" (TORRES, 1978, p. 91) os atores responsáveis pela formação da opinião pública, de maneira a libertá-la da influência nociva do formalismo de bacharéis e "[...] escritores que jamais se detiveram no trabalho de formar ideias gerais sobre seu conjunto, nem no de reunir os dados dos seus problemas" (TORRES, 1978, p. 46).

Nesta conta, seria preciso expropriar o papel da imprensa e da política na direção da opiniáo, transferindo-o para a autoridade do intelectual e do técnico, únicos atores capazes de cultivar a personalidade moral do povo e de forjar uma opinião pública dotada de visão orgânica e empírica sobre os problemas nacionais. Segue-se que, diferentemente da governamentalidade liberal, a formação da opinião aparece aqui completamente apartada da experiência política, transformando-se em voz autorizada pelo suporte da ciência e da técnica.

Portanto, a razão governamental deve guiar a conduta pela fabricação do consenso, mas náo aquele produzido pela socialização política nas praças e nas ruas. Tampouco o consenso da verdade expressa no pleito e no resultado eleitoral, visto que pode ser enganosa quando náo estiver acompanhada da opiniāo autorizada do técnico. Pelo que se depreende da representação comunitária da sociedade, o consenso deve ser alvejado pela diversificação das relaçóes empáticas e das conexóes afetivas mediadas pela ordem estatal, de modo a intervir sobre as disposiçóes emocionais em que se assentam os vínculos morais. 


\section{Revendo a moldura jurídica: do policiamento ao assujeitamento}

Os vínculos morais devem ser lastreados pelas duas principais fontes de produção do sujeito ético: o governo da opinião e o governo da lei, por meio dos quais se mediam as percepçóes e as expectativas, e se delimitam os termos do dissenso. Já comentamos sobre o primeiro. Veremos, então, de que forma Torres investe sobre o segundo como elemento estruturante da interdependência social.

No lugar de uma concepção puramente restritiva e punitiva da lei, que dominaria o regime jurídico vigente na Primeira República, propóe outro regime jurídico, compatível com um governo que tem não o político, mas o social e o econômico como horizonte de inteligibilidade:

A arte de governar tem de abandonar forçosamente o critério político, em suas classificações, para adotar o critério social e econômico, e, nessa esfera, o pêndulo que há de marcar as oscilações do pensamento será o do móvel e o do objetivo da atividade. À noção da lei jurídica, como a concebem os governantes de hoje, deve suceder a da lei vital da sociedade; ao regime das normas e dos preceitos prescritivos e, sobretudo, repressivos e restritivos, a da lei do útil e da finalidade adaptativa (TORRES, 1978, p. 139).

Trata-se aqui de reformar o regime jurídico para promover as garantias contra a carestia, a penúria e outros obstáculos ao desenvolvimento pessoal mais elementar, sem o que não é possível reorientar a política fiscal, dinamizar a produção, ou criar a figura do consumidor. Por essa via, supera-se um regime marcado por uma concepção puramente restritiva e punitiva da lei, incapaz de vincular interesses de grupos sociais distantes. Regime igualmente marcado por um Estado policial, que não produz a obediência pela persuasão, mas, antes, a impóe pelo abuso da repressão violenta e do estado de sítio: "[...] a violência é o agente real da criação e da formação de autoridade, desde que existe entre esta e a sociedade o nexo do mandato por acordo de ideias, da eleição por aceitação de soluçóes" (TORRES, 1978, p. 216).

Para superar esta ordem, não basta uma razão afetiva que produza disposiçóes emocionais e relaçóes empáticas por baixo. Deve-se, igualmente, reprogramar a conduta das elites atuando sobre a sua vontade política e 
seu interesse econômico. Nesta partição, sentimos mais uma vez a presença da escravidáo como forma de sociabilidade, uma vez que, além de legar a indigência às massas, deitou raízes sobre a mentalidade das elites, com sua ética profundamente antieconômica:

O brasileiro não encontra, em nosso meio, desde os primeiros dias da infância, a escola de autonomia e inciativa, que o devia preparar para o trabalho; não recebe a lição de laboriosidade e resistência; não adquire a consciência de que é um produtor, um agente dinâmico da vida social. Nas classes inferiores, o pai, ex-escravo, ex-agregado de fazenda, ou assalariado, não tendo criado amor à sua indústria, habitua os filhos à prática rotineira dos atos mecânicos, de nossas culturas extensivas, quando os não abandona à calaçaria e às portas das vendas. Nas classes médias e elevadas, os incapazes conservam a indústria ou a propriedade paterna, assistindo, inconscientes, à desvalorização das terras e à ruína das fortunas. Os que mostram, na infância e no curso secundário, um pouco de memória e alguma sagacidade, seguem para os cursos superiores, onde ganham com o direito de pretender empregos públicos e cargos de eleição, um desprezo nauseoso pelo trabalho industrial e agrícola. (TORRES, 1978, p. 131-132).

Passagens como essa tomam a escravidão como o nexo moral entre o estrato superior e o inferior, que partilham da paralisia produtiva e da deformaçáo do caráter. Visto desde a razão governamental, é o ofício mecânico e inconsciente do ex-escravo e do dependente pessoal, alienado de qualquer reconhecimento e criatividade, o que os une à indiferença dos especuladores e rentistas, ambos os grupos marcados pela mesma indisposição para a vida pública. As consequências deste desvio são, todavia, distintas: de um lado, desagregação do núcleo familiar e prática de atividades predatórias, como a agricultura extensiva; do outro, incapacidade de geração de riqueza e desprezo pelo trabalho manual.

Reverter esse quadro seria a "tarefa mais urgente de nossa geração". Passaria pela mudança da moldura jurídica, deslocando uma concepção estritamente coercitiva e punitiva da lei por outra mais atributiva, e um modelo de policiamento repressivo por outro de assujeitamento, em que a imposição da obediência dá lugar à sujeição produzida por induções, sugestôes, incitaçôes, e modulaçôes de conduta ${ }^{6}$. Dizer isso não implica,

6 Empregamos a noção de assujeitamento (assujettissement) no sentido formulado por Foucault (2008, p. 243), qual seja, o de "sujeição" dos indivíduos a redes contínuas de obediência e o de subjetivação pela identificação analitica de seus méritos e pela extração das verdades que the são sugeridas por estas mesmas redes. 
no entanto, que esta modulação ocorra de modo semelhante quer estejamos considerando o topo ou a base da pirâmide. É fato que Torres não é explícito e sistemático neste ponto, mas nos fornece alguns elementos que indicam a sua pertinência.

Quando se trata da base, isto é, da massa indigente que corresponde à sua concepção de população e de onde deverá sair o embrião da nacionalidade a ser formada, parece-nos que o foco é a intervenção sobre o regime de interaçôes. Entendemos por isso os agenciamentos afetivos que produzam a estabilidade e a produtividade da família, célula em que se forja e encerra a individualidade pela razão governamental desenhada por Torres. Nesse nível, teríamos o assujeitamento do trabalhador pelo convívio comunitário nas colônias agrícolas, pela educação primária e o acesso aos direitos civis e políticos que lhe são facultados, pelo ensino agrícola voltado para as formas de cultivar a terra, negociar a produção e lidar com as intempéries. Ou seja, investimentos que solidificam a expectativa de futuro, de si e da "prole". Também situamos neste regime de interaçôes as técnicas de cuidado de si, isto é, de reforma dos hábitos por meio da educação sanitária, alimentar e estética, que instauram a problemática do governo no cotidiano e na vida privada.

Por fim, incluímos no regime de interaçôes os espaços de socialização voltados ao estreitamento da interdependência econômica, através do assujeitamento do sertanejo disperso como produtor e consumidor. Aplicam-se aqui "[...] as instituiçóes de mutualidade com fins comerciais, os armazéns gerais, os entrepostos de exportação e consumo; os matadouros, feiras, mercados e depósitos nos centros populosos, combinados com as cooperativas" (TORRES, 1978, p. 209); em suma, espaços funcionais e viveiros de sociabilidade que adensam as relaçôes de troca.

Se é verdade que há aí a possibilidade de um assujeitamento pelo interesse econômico, este jamais é visado a título individual, e sim pela mediação de comunidades morais homólogas à família, como as mutualidades e as cooperativas. A lista se completa com medidas de subvenção de insumos para nacionais e estrangeiros já estabelecidos no país, e a "publicação frequente de cotaçóes de preços correntes, acompanhada de um regime de fiscalização e de polícia econômica, destinado a facilitar os negócios 
entre produtores e consumidores". Neste último caso, trata-se de prover os meios de monitoramento de informaçóes, que assumem um sentido bem próximo ao do regime de opinião antes visto - ou seja, indicadores que sirvam de referente público para as decisóes econômicas -, este característico do liberalismo.

Quando atravessamos a escala para chegar ao estrato superior, defrontamo-nos com outro tipo de assujeitamento, embasado no ajustamento do interesse econômico e da vontade política das elites dominantes. Diferentemente do que vimos para a base, não é o caso aí de trazer de forma subordinada para a vida pública a massa que dela está excluída, mas de reorientar a conduta de quem é nela o ator por excelência. Trata-se de governamentalizar as elites pela remoção do estadualismo oligárquico na política e pela reversão da especulação improdutiva da propriedade e do desapreço contra o trabalho manual na economia. Medidas que promoveriam a esfera pública nacional.

As medidas práticas anunciadas por Torres (1978, p. 205-206), de uma maneira ou de outra, atuam sobre o interesse econômico, por meio da promoção do incentivo fiscal, da redução das despesas e dos impostos de exportação, da concessão de crédito e da amortização de dívidas. Em seu conjunto, permitiriam diminuir a ociosidade das grandes propriedades, aumentar e diversificar os gêneros de exportação, balancear a tributação segundo a capacidade de pagamento dos estados e proteger a produção nacional contra a pressão dos juros e a concorrência estrangeira. Além disso, visa-se estabelecer o regime comercial orquestrado por uma política nacional, que vincula os mecanismos de proteção à observação dos compromissos exigidos em caso de recurso ao crédito ou aos "favores dos poderes públicos”. Trata-se de promover uma mentalidade compatível com o cálculo dos riscos, acenando aos especuladores e rentistas com os ganhos líquidos que adviriam de uma mudança de seu agenciamento econômico.

Assim como o agenciamento do grande proprietário é afetado pela produção de novas liberdades econômicas, o interesse das elites regionais é visado pela maximização dos benefícios concedidos aos estados e municípios, que emergiria com a cooperação de esforços em uma ordem estatal autônoma. 
"A prática política teria concorrido para desvirtuar a Constituição e as instituiçôes" (TORRES, 1978, p. 72). Os estados selaram sua supremacia sobre a união, decidindo sobre as condiçóes de intervenção federal, quase que exclusivamente limitada à decretaçáo do estado de sítio, recorrendo às tropas federais para assegurar seus ganhos privados face à ameaça de levantes e agitaçóes populares. Assim, teriam sido "os homens políticos da república, estadualistas por amor local e por força do interesse representativo" os algozes responsáveis pela ausência de uma coordenação nacional (TORRES, 1978, p. 74).

Somente por meio da fundação da "sociedade governamental", "característica dos governos democráticos”, "é que se poderá elevar o valor moral dos governantes" (TORRES, 1978, p. 97). Novamente somos levados pela lógica dos benefícios de uma transformação estrutural, em média e longa duração, mas que, paradoxalmente, se pretende não apenas compatível como restauradora do espírito da Constituição de 1891, o que reafirma a concepção da revolução governamental como contrarrevolução política, discutida anteriormente.

Como, então, estimular a vontade política dos representantes das oligarquias estaduais para que eles não apenas aceitem como demandem, por iniciativa própria, ações de cooperação e intervenção federal, de modo a diminuir os custos de combate a males públicos, como as epidemias e as endemias? É importante ressaltar que Torres não coloca esta questão. Pensa na coordenação nacional de forma abstrata e basicamente vitalista, embora assinale a importância dos convênios entre uniáo, estados e municípios como instrumento privilegiado para a construção de um pacto federativo que servisse de base à "organização nacional", ainda que com um evidente protagonismo do executivo (TORRES, 1978, p. 243).

Temos, portanto, alguns elementos dispersos, porém consistentes, que apontam para a partição tática do assujeitamento, em ambos os casos baseada na reforma da moldura jurídica. De um lado, o polo da massa, alvejada a partir da regulaçáo dos corpos e de seu comércio afetivo, no cotidiano e nas interaçóes. Do outro lado, está o assujeitamento das elites, com base no reconhecimento da soberania individual e na produção de liberdades econômicas pelo ajuste das vontades. É neste último polo 
que encontramos a mentalidade de governo típica do liberalismo, ou seja, a estimulação da racionalidade econômica e do cálculo dos riscos, meios de fabricação do sujeito autônomo. Para examinarmos a concepção e a política de população nesta razão governamental, é ao primeiro polo que devemos voltar nossa atenção.

\section{Por uma política de população}

Fundar a ação pública nos processos que constituem a população e seu governo. Parece-nos ser este o deslocamento que a contribuição de Torres opera sobre o modelo de povoamento da Primeira República, visto por ele como o responsável pelas assimetrias entre o mundo urbano e o rural, entre o litoral e o interior. Um modelo incapaz de integrar as elites a um projeto nacional ou de transformar o lavrador em produtor e consumidor e, portanto, de dinamizar a economia e formar a sociedade.

Comentar não acerca da soma de aldeamentos e agrupamentos humanos, mas da população como objeto de governo pressupóe projetá-la em devir permanente, ou seja, tomar a sua conformação histórica, a sua distribuição geográfica, o seu movimento demográfico e a sua estratificação econômica como referente fundamental do governo, ainda que os modos de representar e agir sobre ela sejam variáveis historicamente. Nesse sentido, somente é lícito falar em uma política de população quando esta é representada como força que pode ser expandida e estimulada, que pode ser otimizada pelo Estado, mediante intervençóes urbanísticas e sanitárias da biopolítica. Ou, ainda, ser evocada como barreira contra as ações deste mesmo Estado, como na crítica da economia política ao "excesso de governo".

Veremos, nesta seção, como a reflexão torreana alça a população à condição de grade de problematização não da riqueza, mas da prosperidade nacional; não do território, em seus recursos naturais e constituição física, mas da própria agência humana. Para tanto, três obstáculos deveriam ser removidos: o patriotismo ancorado na tradição e no parentesco; o meio e a raça como variáveis determinantes do desenvolvimento nacional; o modelo de povoamento e extração da riqueza, ancorados em uma política territorial descolada das características e da densidade da população. 
A superação do patriotismo tradicional, para Torres (1978), é “[...] sentimento instintivo que une o homem à terra natal” (p. 106), pelo nacionalismo moderno, "um móvel afetivo racional" (p. 123), o qual corresponde ao deslocamento do território como fonte principal de identidade e pertencimento comunitário, que confinava os grupos sociais em solidariedades locais, por meio da tradição, da ancestralidade e da oralidade. Logo, contra este patriotismo instintivo, que oscila entre a estetização da natureza e o sentimento belicoso de negação do inimigo, é preciso promover a "sensação de segurança e proteção legal que tranquiliza os espíritos nas sociedades modernas” (TORRES, 1978, p. 112).

Há um evidente sentido de ruptura e urgência que preside o devir histórico, uma vez que o nacionalismo não brotará do simples decurso do tempo ou dos estágios da civilização, e sim de uma ação organizada, segundo o princípio de utilidade que caracteriza a "sociedade governamental". O território perde sua dimensão sagrada, um limite que a natureza impóe ao governo, para se tornar sua fronteira, um convite à expansão da agência humana. Este aspecto, determinante para uma política de população, fica mais transparente quando revisamos o lugar que ocupam o meio físico e a raça na ideia de nação.

\section{a) Raça e meio, entre a divisão e a coesão}

A posição de Torres sobre a questão racial é um tanto controvertida. Por um lado, situa-se entre os que negam a cientificidade do argumento sobre a pureza das raças atávicas, que remonta a Gobineau e Agassiz. Por outro lado, sua voz está entre as poucas dissidentes da tese do branqueamento, formulada por Silvio Romero, que buscava contornar o fatalismo que o olhar europeu reservava aos trópicos, ao conciliar a realidade da mestiçagem com a promessa de futuro. De acordo com esta corrente, no intervalo de algumas geraçóes, negros e mestiços seriam eliminados pela introdução massiva de sangue branco aportado pela imigração europeia no país (SCHWARCZ, 1993; SKIDMORE, 1991). Contra estas prediçôes, o autor relativizou o papel da raça como elemento da nacionalidade, enquanto enxergava no caldeamento étnico do Brasil um importante aspecto formativo da comunidade moral. 
Torres procurou demonstrar que a miscigenação estaria na própria origem dos povos europeus, citando a composição tripartite da Suíça, a diversidade étnica dos Estados Unidos e a fusão de teutos, hunos e magiares na formação da Áustria-Hungria. Ao afirmar que “[...] nenhum dos povos contemporâneos é formado de uma raça homogênea e alguns se compóem de raças distintas", desfaz-se do paradoxo do branqueamento pela miscigenação; ainda que "[...] o Brasil conte exemplares de raças extremas, somente um cuidadoso estudo etnológico autorizaria a classificação de cada alemão de Blumenau como germânico, e de cada italiano, espanhol ou português de São Paulo, de Minas e do Rio de Janeiro como latino" (TORRES, 1982, p. 28). A tese do branqueamento corresponderia à ilusão de que seria possível subverter o hibridismo na origem e realizar a utopia da uniformidade étnica no futuro.

Com esta visão, Torres situava-se entre os que defendiam ideias antirracistas, justamente no período da hegemonia do racismo científico, contribuindo para formar a representação do Brasil como nação mestiça e tolerante, que atingiria seu paroxismo com Gilberto Freyre, nos anos 1930. Ao lado de Manoel Bomfim, de Roquete-Pinto e dos médicos sanitaristas, Torres negava radicalmente o dogma da desigualdade racial, concebendo o preconceito de cor como um reflexo da desigualdade social. Uma vez que se verificasse a integração das populaçóes abandonadas e o adensamento moral da sociedade brasileira, a insularidade dos agrupamentos sociais seria superada e o preconceito racial desapareceria. Como afirmou Sergio Costa (2003, p. 114), trata-se de uma atitude incompatível com o pensamento antirracista contemporâneo, que vê na explicitação das classificaçóes raciais a única possibilidade de combater o racismo embutido nas práticas culturais e nas formas de distribuição das oportunidades sociais.

Naquele contexto, entretanto, a contestação do racismo era bastante progressista e, em autores como Torres, relacionava-se à defesa de um olhar menos etnológico e mais sociológico sobre a população. Por isso, era preciso desfazer a representação antinômica colonialista que projetava as naçóes europeias como constituídas por populaçóes racial e culturalmente homogêneas, e mostrar que as naçóes oriundas da mistura poderiam ser viáveis (COSTA, 2003, p. 123-124). Neste ponto, Torres aproximava-se de Manoel Bomfim, que se esforçava por mostrar que os Estados Nacionais 
são fusões de tradiçôes culturais e grupos étnicos diversos, unificados em torno do "tipo psicológico que define a nacionalidade" (BOMFIM, 1997, p. 187). Para ele, o mestiço não representava a transição para o branco, como queriam Silvio Romero e Oliveira Vianna, mas o tipo racial novo, a forma acabada e estável da nacionalidade.

Diferentemente de Bomfim, contudo, Torres interpreta o caldeamento étnico e cultural que produziu nossa formação social como um ponto de partida da ação governamental. Em vez de se basear no afluxo de imigração e no decurso impreciso de geraçóes, como queria o branqueamento, uma política racial eficiente deveria mirar "[...] na consolidação do caráter do povo, pela educação; na defesa da sua economia física, pela alimentação e pela higiene pessoal, doméstica e pública; na defesa da sua economia social, pela política econômica" (TORRES, 1982, p. 71).

Nesse argumento, a raça deixa de ser um fator de fratura interna, ou, ainda, o principal elemento de uma nacionalidade inconclusa para se tornar um componente da vitalidade da população, que deve ser protegido e fortalecido. Uma posição que se harmonizava bem com o cenário dos anos 1910 e 1920, quando a carestia, a insalubridade e o analfabetismo passaram a ser valorizados como males públicos, e problematizados por atingirem transversalmente a população.

Uma cisão importante se operou entre as elites intelectuais, que até então não hesitavam em "[...] tomar as raças e a miscigenação como limites básicos para a atualização do Brasil e sua adequação aos padrôes do mundo civilizado" (OLIVEIRA, 1990, p. 145). Os aspectos constitutivos do meio e da raça, que faziam da nacionalidade a matriz explicativa da realidade, sucumbem à saúde e à educação enquanto fonte de subjetivação do homem nacional.

No debate intelectual, raça e racialização assumiriam novos sentidos. Também aqui, Torres não estava sozinho. Por um lado, o movimento sanitarista enfatizava a irrelevância da raça como categoria explicativa para a doença. Seus principais nomes, como Belisário Penna, Arthur Neiva, Miguel Couto e Afrânio Peixoto, insistiam que a ancilostomíase e outras moléstias constituíam elementos de "nacionalização" do imigrante, vítima, da mesma forma que o trabalhador nacional, da "pandemia da preguiça" 
(PENNA, 1918 apud LIMA, 1999, p. 104). Entre os intelectuais que aderiram à campanha pelo saneamento dos sertóes, a despeito de persistirem estereótipos e afirmaçóes em que aparecem ideias associadas a diferenças raciais, pode-se afirmar um claro predomínio de um discurso que refutava a atribuição da inferioridade étnica à população brasileira. Um movimento de desracialização da doença e dos fatos biológicos, portanto.

Por outro lado, o termo "raça" tornou-se táo ou mais empregado do que antes, passando a carregar bastante imprecisão e a se referir ao conjunto do povo brasileiro. Um fato novo, mas não contraditório. Embora os adeptos do antirracismo refutassem a biologia como matriz explicativa dos diferentes níveis de progresso material e moral entre as várias sociedades, partilhavam de um conceito de cultura e civilização no singular. A civilização europeia constituía o padrão que empregavam para medir o grau de desenvolvimento dos povos, permanecendo a meta a ser alcançada em todas as regióes do mundo. $\mathrm{O}$ que possibilitava a rejeição da raça como categoria de análise das diferenças humanas era justamente a racialização da cultura, que começava a orientar o pensamento social. Este quadro estabelece alguns limites claros ao antirracismo de Torres, mas também chama atenção para as articulaçóes entre a racialização da cultura e a política de população, que apontam para o novo uso da "raça", subordinado às reflexôes sobre a interdependência social.

O sanitarismo alcança seu apogeu no Brasil dos anos 1920, momento de recepção das ideias da eugenia, entendida como o aprimoramento das novas geraçóes. Torres é um dos primeiros a evocar estas ideias. Já em 1912, reputava que uma "política eugênica bem inspirada, sincera e conscientemente preocupada em facilitar e favorecer o desenvolvimento espontâneo do homem brasileiro, nas melhores condiçóes de adaptação e progressividade deve procurar, esforçadamente, manter puros os tipos étnicos aclimados, para que estes, evoluindo naturalmente, manifestem e desenvolvam os caracteres próprios” (TORRES, 1982, p. 77).

A nosso ver, a condenação aos "cruzamentos inter-raciais" para proteger a adaptabilidade adquirida pelos tipos étnicos originais náo deve ser vista como uma defesa do determinismo mesológico ou climático. Como mostrou Nancy Stepan, a recepção da eugenia e seu vocabulário racialista 
na América Latina esteve associada à reivindicação de uma legislação de proteção social que pudesse promover a condição mental, física e moral dos mais pobres. Este entendimento estava de acordo com a vertente neolamarckiana da eugenia, de origem francesa e hegemônica no Brasil. Segundo esta corrente, os melhoramentos adquiridos na relação do indivíduo com o meio físico e social durante seu curso de vida seriam incorporados ao seu patrimônio genético, modificando sua aptidáo para a seleção natural (STEPAN, 1991, p. 74).

Os sanitaristas, assim como Torres e a maior parte dos intelectuais brasileiros seriam bastante sensíveis à chamada "eugenia positiva”, isto é, à defesa do "melhoramento da raça" com base na ação sobre o meio social, a conduta e as condições de vida. Muito diferente, portanto, da posição dos porta-vozes da "eugenia negativa", como Renato Kehl, publicista inveterado das teses de controle de casamentos, de esterilizaçáo dos miscigenados, e das cotas raciais para a imigração (LIMA, 1999, p. 115).

Paradoxalmente, a defesa intransigente do hibridismo étnico que nos caracteriza como nação passava pela preservação da pureza racial dos grupos aclimados, pois, ao contrário do que se deu nas matrizes europeias, tais grupos se encontravam sob perigo de desaparecimento, por não terem sido integrados ao aparelho produtivo. Devemos relembrar a insistência de Torres em proteger a população, massa depauperada situada entre o eito escravista e a classe senhorial, contra o abandono que lhe foi destinado, a desorganizaçáo da produçáo e a concorrência desleal com os imigrantes por postos de trabalho. A eugenia positiva encontra-se, assim, integrada à política de população, de modo a revitalizar os núcleos formadores e prepará-los para a assimilação do imigrante, evitando a descaracterização da nacionalidade.

\section{b) $O$ povoamento como fonte de integração social}

A lógica de povoamento por imigração, herdada do império e alçada na república a uma das mais importantes políticas de Estado, é um dos principais alvos de $A$ organização nacional e $O$ problema nacional brasileiro, e inseparável de sua crítica ao modo então preferencial de ocupação e exploração do território. 
O povoamento que se praticava consistia na atração de imigrantes para trabalharem na lavoura, especialmente naquelas destinadas ao cultivo dos gêneros de exportação. Uma dispendiosa propaganda no exterior buscava fixar o estrangeiro em solo nacional, idealmente por laço matrimonial com uma brasileira, atenuando-se as exigências para naturalização. No entanto, longe de organizar o trabalho, o agenciamento de forasteiros reforçava a economia dirigida para a exportação, a taxaçáo e o ganho especulativo. Incluíam-se aí as obrigaçóes contratuais assumidas pelo imigrante que teve sua passagem subvencionada, como os empréstimos a juros quase impagáveis, o trânsito controlado e a restrição da compra de alimentos às imediaçóes da fazenda. Recursos que escasseavam a mobilidade social, e até mesmo física, do trabalhador, aprisionando-o a uma situação de dependência pessoal.

Não é difícil perceber que esse tipo de trabalho semidependente dificilmente poderia dar origem a um padrão de consumo, e que sequer era alvejado como fonte de renda para efeito de ampliação do consumo nacional. Nesse quadro, o autor se esforçou por mostrar que o modelo de povoamento encampado pela república minimizava as possibilidades de diversificar a produção e desenvolver o mercado interno, enquanto escapava à problematizaçáo das condiçóes de trabalho e reduzia a visão de povoamento ao mero aumento absoluto da população e ao crescimento dos setores comerciais ligados à exportação.

Em relação ao território, o povoamento não é, por si só, nem um bem, nem um mal; mas no interesse do território, o objetivo político deve ser [...] o do seu aproveitamento útil, em benefício geral, pela conservação das fontes matrizes das riquezas, dos elementos primários de produção, de correção e reparação das condições secundárias da produtividade. Povoar um território sem educar o homem para a produção econômica, sem organizar o trabalho, é o mesmo que roubar a terra e causar mal ao homem, fazer das populações infecções corroedoras da superfície do solo. Este povoamento nós o temos feito, como todos os povos novos; tal será o resultado da colonização como tem sido praticada. (TORRES, 1982, p. 108-109).

O volume da população pode ser ilusório se não assenta sobre a densidade das trocas e interaçóes que a infraestrutura existente permite estimular: "[...] a devastação de novas regióes para colonizar não dá senão a ilusão do aumento da população. Ainda por essa forma, o caráter da população que se estabelece e a natureza da exploração são tão instáveis que 
não ocorre efetivamente aumento" (TORRES, 1978, p. 188). Como peça de propaganda, o povoamento pode mascarar os desarranjos na estrutura econômica e aprofundar a ocupação irregular. Neste caso, tal como a visão estática da raça, constitui náo uma possibilidade, mas um limite ao governo, impedindo a criação de ambientes artificiais monitorados a distância, ao longo do território.

Entre os vícios inerentes a este modelo, encontra-se a construção das estradas de ferro, por não ter como objetivo o desenvolvimento da população. Além de expulsar assentamentos humanos, sem planejar sua realocação, a localização das vias férreas era determinada por clientelismo e acordos entre as oligarquias, e na preferência em interligar cidades e estados estratégicos para a agroexportação:

[...] as estradas de ferro não entrelaçam as populações do interior, umas com as outras; não formam redes de relações recíprocas, movimentando a circulação interna: são vias de drenagem e de atração de povos e riquezas para as praças comerciais, para as capitais, para os portos, para os centros de negócio e de luxo. (TORRES, 1978, p. 192).

Com efeito, as estradas são a causa da migraçáo descontrolada e da desarticulação da vida rural. Personificam a imagem inventiva do autor, que opóe a civilização construída no litoral às expensas da barbárie do interior abandonado, exprimindo a relação parasitária que se estabeleceu entre um e outro, tema fundador da sociologia brasileira, como mostrou estudo de Nísia Trindade Lima (1999).

Não bastasse isso, as vias férreas são o melhor exemplo da atitude imitativa e reverente das elites governantes, uma importação custosa e contraproducente que elas foram buscar na Europa e nos Estados Unidos, mas que não cumpre sua função de integração nacional, porque não foram observadas as condiçóes históricas que devem determinar sua pertinência e aplicação. Nossos estadistas não teriam entendido “[...] que a viação férrea foi estabelecida, na Europa, a fim de ligar densas populaçóes já existentes, e se foi desenvolvendo, nos Estados Unidos, conjuntamente com a população" (TORRES, 1978, p. 190-191).

Consequentemente, a ligação ferroviária deveria ser descartada como opção em países que não conhecem uma forte densidade populacional. 
Mais do que isso, ao introduzir a variável fundamental da densidade demográfica, Torres sugere que é sobre ela que a ação governamental deve incidir; afinal, uma densidade relativamente alta e balanceada em nível nacional é sinônimo de um crescimento embasado no investimento em bens e equipamentos públicos, sem os quais não é possível organizar o trabalho como fonte de produção da riqueza.

Também aqui a reflexão de Torres acompanhava a mudança mais ampla na racionalidade política. A problematização do território e da ocupação pela dinâmica demográfica da população encontrava-se no âmago do discurso estatístico daquele momento. Veja-se o caso do Censo de 1906, o primeiro a privilegiar a densidade demográfica da capital federal, chave para o zoneamento sanitário da cidade e para a visualização dos focos epidêmicos, que estavam sendo erradicados pela reforma sanitária. A densidade também importava como meio de visualização das moradias urbanas, porque a inspeção e a regulação estavam entre as principais estratégias para o saneamento do Rio de Janeiro. Tanto que um segundo volume, inteiramente dedicado à estatística predial, destacava os níveis de aglomeração e as condiçôes sanitárias de habitação e coabitação, principal alvo da política de saúde que então se implementava (CAMARGO, 2016, p. 368-369).

A nova preocupação com a densidade demográfica apontava para o reconhecimento das dinâmicas socioespaciais que regem o movimento da população. É nesse sentido que devemos compreender sua condenação à imigração, quando praticada sem atenção ao perfil da população e da ocupação do território, uma vez que subverte o crescimento considerado "normal", ou seja, aquele que se verifica quando o governo busca remover os obstáculos à expansão das forças que constituem a população (CAMARGO, 2016).

\section{Considerações finais}

Neste artigo, examinamos as linhas motoras de uma razão governamental que nos parece sistematizada pelo pensamento de Alberto Torres. Tal pretensão nos permite superar os limites da análise que relaciona sua obra a uma matriz de pensamento autoritário ou conservador. Ao invés disso, procuramos seguir uma perspectiva capaz de vislumbrar a continuidade renovada de uma estrutura de sociabilidade tradicional em meio à 
ruptura das novas formas sociais promovidas pela estatização da sociedade e pelo Estado fundado na razão governamental. Desta ruptura resulta uma hibridização entre o velho e o novo, que mescla transformação estrutural e preservação da ordem constitucional; revolução cultural e contrarrevolução política, regulação da agência e conservação orgânica; superação da dependência pessoal e afetividade comunitária; disciplinamento dos corpos e soberania da vontade; intelectualismo e autonomia da opinião.

Vimos que Torres não escreveu alheio a seu tempo e seus contemporâneos. A reflexão sobre a razão afetiva na relação entre natureza e sociedade é claramente influenciada pelo vitalismo. A recusa da raça como categoria analítica encontrava seus limites na noção evolucionista de cultura, visão comum a outros autores que não se alinhavam com a tese do branqueamento, como Manoel Bomfim. À maneira dos sanitaristas, a defesa da eugenia positiva visava a construir o sujeito ético e o homem nacional pela ação sobre as condiçóes de vida dos agrupamentos humanos. $\mathrm{O}$ mesmo pode ser dito em relação à preocupação com a densidade demográfica e as dinâmicas socioespaciais, que começavam a figurar nos dispositivos de quantificação da população, como o censo de 1906. Ao destacarmos a racionalidade política que unia Torres a outros atores e movimentos do seu tempo, tentamos mostrar que o elo entre o tradicional e o moderno é uma chave importante para compreender sua gigantesca e imediata influência.

Por um lado, a política de população preconizada por Torres é profundamente marcada pelo problema fundamental da integração subordinada das massas. Por outro lado, sua obra se reaproxima do liberalismo ao tratar da governamentalização das elites, especialmente no tema da coordenação ("cooperação") nacional. Assim, por exemplo, ao afirmar que "[...] autonomia e soberania, descentralização local e força política da União deixam de ser elementos discordantes, para se tornarem verdadeiros tecidos que se integram e se completam, no fim comum do bem do homem" (TORRES, 1978, p. 243), valida um postulado essencial do liberalismo: o princípio da autonomia é a fonte que produz e circunscreve a soberania.

O conservadorismo é matizado pelo liberalismo, que, como defendemos, está no pano de fundo da sua reflexão. Gabriela Nunes Ferreira chamou atenção para sua adesão aos princípios da democracia liberal. Além 
da manutenção do sufrágio universal, sua obra defende o habeas corpus, a igualdade dos indivíduos perante a lei, o direito à propriedade, a liberdade de imprensa e a liberdade política. A crítica ao regime federativo se faz muito mais em relaçáo aos seus excessos, que impediam o Estado de tematizar e proteger os desejos e anseios da população. Corrigida a distorção do estadualismo, o federalismo mantinha-se como regime ideal para as dimensôes continentais e as especificidades regionais do país. Por sua vez, a representação classista restringia-se a uma parte da composição do senado, para fazer frente ao elevado número de profissionais liberais e funcionários públicos, de modo a refletir de forma mais fidedigna a correlação de forças existente na sociedade. Buscando refinar a representação política diante do avanço da divisão do trabalho, alinhava-se aos reformadores liberais europeus. Por fim, seu plano para os partidos políticos objetivava transformá-los em plataformas de coesão ideológica, expressão dos interesses antagônicos dos grupos sociais (FERNANDES, 2010, p. 111-114).

Ao lado desses traços mais institucionais, nosso argumento procurou mostrar como a racionalidade política do liberalismo se faz presente na obra torreana. Ela se encontra na concepção de governo como campo de possibilidades da agência social, a partir do qual as técnicas de si e as instituiçóes garantidas ou certificadas pelo Estado visam a incitar e induzir determinadas açóes, em detrimento de outras. Deste ponto de vista, notamos um viés mais marcadamente liberal, relacionado à persuasão e ao contrato, em matéria de coordenação, quando estão em jogo as vontades de um pacto societário (federativo). Em outros momentos, esta inclinação se arrefece, quando a atenção se desloca para os temas de população, alvejados pela lógica afetiva das interaçóes comunitárias. Este importante aspecto de seu pensamento tem sido negligenciado tanto pela crítica liberal do autoritarismo e da centralização, quanto pelos partidários da expansão da regulação estatal. Uma lacuna que o presente artigo pretendeu preencher.

\section{Referências}

BOMFIM, M. O Brasil na América: caracterização da formação brasileira. 2. ed. Rio de Janeiro: Topbooks, 1997. 
CAMARGO, A. P. R. A construçáo da medida comum: estatística e política de população no Império e na Primeira República. 2016. 362 f. Tese (Doutorado em Sociologia) - Programa de Pós-Graduação em Sociologia, Universidade do Estado do Rio de Janeiro, Rio de Janeiro, 2016.

CARVALHO, J. M. Cidadania no Brasil: o longo caminho. 13. ed. Rio de Janeiro: Civilização Brasileira, 2010.

COSTA, S. 2003. Paradoxos do pensamento antirracista brasileiro. Teoria \& Pesquisa, n. 42-43, pp. 11-130, 2003.

FERNANDES, M. F. L. O pensamento político de Alberto Torres: a reforma constitucional e o Estado brasileiro. In: BOTELHO, A.; FERREIRA, G. N. (Org.). Revisão do pensamento conservador: ideias e política no Brasil. São Paulo: Hucitec, 2010. p. 95-118.

FOUCAULT, M. Les techniques de soi. In: DEFERT, D.; EWALD, F. (Org.). Dits et écrits (19541988) par Michel Foucault. v. IV (1980-1988). Paris: Gallimard, 1994. p.? 783-313

FOUCAULT, M. Segurança, território, população. São Paulo: Martins Fontes, 2008.

FOUCAULT, M. O nascimento da biopolítica. São Paulo: Martins Fontes, 2009.

HOCHMAN, G. A era do saneamento: as bases da política de saúde pública no Brasil. São Paulo: Hucitec, 1998.

IGLÉSIAS, F. Prefácio. In: TORRES, A. A organização nacional. 3. ed. São Paulo: Cia. Editora Nacional; Brasiliana, 1978. v. 17.

LAMOUNIER, B. A Formação de um pensamento político autoritário na Primeira República: uma interpretação. In: FAUSTO, B. (Org.). História Geral da Civilização Brasileira. Tomo III: O Brasil Republicano, volume 2: Sociedade e Instituiçôes. 5. ed. São Paulo: Difel, 1985. t. 3. vol. 2. p. 343-374.

LEMOS, M. T. T. B. Alberto Torres: contribuição para o estudo das ideias no Brasil. Rio de Janeiro: Quartet editora e comunicaçáo, 1995.

LIMA, N. T. Um sertáo chamado Brasil: intelectuais e representação geográfica da identidade nacional. Rio de Janeiro: Iuperj; Revan, 1999.

MARSON, A. A ideologia nacionalista em Alberto Torres. São Paulo: Duas Cidades, 1979.

NAGLE, J. A educação na Primeira República. In: FAUSTO, B. (Org.). História geral da civilizaçáo brasileira. Tomo III, v. 9: O Brasil republicano, volume 2: Sociedade e instituiçóes (1889-1930). 8. ed. Rio de Janeiro: Bertrand Brasil, 2006. p. 259-291.

OLIVEIRA, L. L. A questáo nacional na Primeira República. São Paulo: Brasiliense. 1990.

SANTOS, W. G. Ordem burguesa e liberalismo político. São Paulo: Duas Cidades, 1978.

SCHWARCZ, L. M. O espetáculo das raças: cientistas, instituiçôes e questão racial no Brasil. São Paulo: Companhia das Letras, 1993. 
SKIDMORE, T. Preto no branco: raça e nacionalidade no pensamento brasileiro. 2. ed. Rio de Janeiro: Paz e Terra, 1989.

STEPAN, N. The hour of eugenics: race, gender and nation in Latin America: New York: Cornell University Press, 1991.

TORRES, A. A Organizaçáo Nacional. 3. ed. São Paulo: Cia. Editora Nacional; Brasiliana, 1978. v. 17.

TORRES, A. O Problema Nacional Brasileiro: introdução a um programa de organização nacional. 4. ed. Brasília: Ed. UnB, Temas Brasileiros, 1982. v. 35.

\section{The governmental reason of Alberto Torres}

\section{Abstract}

This paper seeks to investigate the work of Alberto Torres focusing the rise of a governmental reason in Brazilian political thought, which is grounded on the logic of prevention and the shaping of a field of possible actions. Michel Foucault's contribution on governmentality provides a theoretical frame to examine the author's understanding of modernization, it argues that the architecture of the State designed in $A$ organização nacional and in 0 problema nacional brasileiro is inseparable from the making of the "homem novo" as an ethical subject capable of facing the risks of social life, what constitutes a landmark in the tradition of political and social thought. Thus, governmental reason is analyzed on the following aspects: the influence of slavery sociability on the conception of population, based on affection and community interactions; the reform of law and the conditions for the rule of opinion, fostering the government of perceptions; the place of racial politics and territorial settlement in the expansion of the state's administrative capacity and in the regulation of human agency.

Keywords: Governmentality. Politics of Population. National Coordination. Social Thought. Early Republic. 